\title{
The Self of Sundanese Ethnic: Interdependent Construal and Religious Self
}

\author{
Retno Hanggarani Ninin ${ }^{1}$ \\ ${ }^{1}$ Faculty of Psychology, Padjadjaran University, Bandung, Indonesia \\ Correspondence: Retno Hanggarani Ninin, Faculty of Psychology, Padjadjaran University, Bandung, Indonesia, \\ Jl. Raya Bandung-Sumedang Km 21, 45363, Indonesia. Tel: 022-779-4126/7. Fax: 022-8792-0376. E-mail: \\ retnoninin@gmail.com
}

$\begin{array}{lc}\text { Received: November 16, } 2014 & \text { Accepted: May 11, } 2015 \quad \text { Online Published: May 30, } 2015 \\ \text { doi:10.5539/ass.v11n16p1 } & \text { URL: http://dx.doi.org/10.5539/ass.v11n16p1 }\end{array}$

\begin{abstract}
This paper aims to introduce the religious self-viewed from the Indonesian context. Indonesia is a large country with diverse ethnic groups and the study seeks to investigate the self in relation to ethnicity. Specifically, the study examines the Sundanese ethnic group that has relatively few sub-groups compared with others found on the archipelago. The study undertakes a conceptual analysis to illustrate the religious self. In this regard, the social and cultural factors are examined to enable a proper account of the religious self, particularly in Indonesia. Relevant empirical evidence is presented to support and explain the religious self-concept. The study further presents a comparative analysis with previous self-concept studies. Finally, the paper concludes with a discussion on the direction of future research on the religious self.
\end{abstract}

Keywords: interdependent, religious, self, Sundanese ethnic

\section{Introduction}

The last decade has seen a rapid change in the social psychology theories of the self that are influenced by the desire to understand and to explain social behavior. The different studies on the self-have given rise to variations in the concept of the self. There is ongoing research in traditional areas which inlcude the personal self (Bennett, 2011), the social self (Forgas \& Williams, 2003; Mead, 1913), the true self (Miller, 1991) and self-concept (Kim, Chiu, Cho, Au, \& Kwak, 2014; Gaertner, Sedikides, \& O'Mara, 2008). The most interesting developments in relation to the self are in the neuroscience area (Ng, Ha, \& Lai, 2010; Schmeichel, Vohs, \& Baumeister, 2003) and in its implementation relative to physical health (Hardie, Critchley, \& Morris, 2006; Logel \& Cohen, 2011). Numerous self-related studies connect self-concept with culture (Fang, 2010; Hepper, Sedikides, \& Cai, 2013; Kim, 2011; Lu \& Yang, 2006; Markus \& Kitayama, 2003; Mookherjee, 2013).

There is a significant increase in the number of studies concerning cultures-particularly from the Eastern cultures- specifically studies about the self, after the various cross-cultural studies which have continued to confirm that there are some differences between the Western self and the self of individuals from the Eastern cultures. The first culture-studies focused on the differences between individualistic (Western) and collectivist (Eastern) cultures, with a particular emphasis on the feature-rich and complex Eastern cultures. The scope of such studies have since expanded to investigate the self-features of people from the Eastern societies. These Eastern self-feature studies have shown that individuals from certain cultural backgrounds have unique self-features. For instance, the Confucian self or the Confucian social self which are identical of the Chinese ethnic or people (Fang, 2010; Kim, 2011). Other studies showed specific Korean self-feature (Kim, Kim, Kam, $\&$ Shin, 2003) and South Asian (particularly Indian) self-features (Mookherjee, 2013).

The Eastern cultures are inseparable from their religions. Religion is one factor that shapes culture; for example Taoism or Buddhism in China; Shintoism in Japan; Hinduism in India; and Islam in Turkey, the Middle East and several Asian countries including Pakistan, Bangladesh, Indonesia and Malaysia. This has encouraged the emergence of studies on the religious self, in the context of religion as a culture (Perreira, 2010).

In contrast with the relatively mono-ethnic countries such as China and Taiwan-with a majority of ethnic Chinese-or Korea, Japan and India, Indonesia is unique in its multi-ethnicity. Its major ethnic groups include Javanese, Malay, Batak, Dayak, Bugis, Minang, Sunda and Betawi. Each of these ethnic groups have various 
sub-groups. For example, the Dayak people have 40 ethnic subgroups including Dayak Agabag, Tidung, Tegalan, Akolod, Taghol, Murut, Kenyah, Lepo'Ke, Merap, Punan, Bidayuh, Iban, Embaloh and Siang (Kopassus, 2012).

When investigating the Maluku region, the 2014 Indonesian expedition differentiated the Ambon ethnic group into hundreds of sub-groups, each of which had a different culture (Kopassus, 2014). Culture, as a collection of beliefs, values and ways of viewing things that is internalized by its members to construct individual beliefs, values and ways of viewing things, can potentially influence the self. Cultural differences may thereby result in differences in the self between the various cultures. Such cultural differences result in nomothetic self-feature differences between individuals of the same cultural group, rather than in idiographic features of the individual self. The self can be conceptualized as a cultural self (Lalwani \& Shavitt, 2009; Lu \& Yang, 2006; Markus \& Kitayama, 2003).

The Sundanese ethnic group was chosen to model the Indonesian cultural-self because 1) they are one of the few ethnic groups in Indonesia without numerous ethnic sub-groups and whose people still relate strongly enough with their culture to have a cultural self; and 2) like the Minang and Balinese cultures, the Sundanese are highly influenced by religion (Islam in the Sundanese and Minang cultures and Hinduism in the Balinese culture). This means that a study on the cultural self is inseparable from the religious self. This study investigates the cultural self and the religious self of the Sundanese people. The resulting model is compared with the previous concepts of the cultural self. The paper concludes by indicating the future direction of research on the cultural self and the religious self.

\section{The Indonesian Muslim Religious Self}

Sociology treats religion as an institution (Schaefer, 2009), whereby a person can join as a member and there are membership consequences. These include demands to comply with the rules that bind the members to the religion and reward and punishment mechanisms for every compliance with and violation of such rules. Anthropology, however, gives religion the same status as ethnicity and gender: traditionally, this is the ascribed status acquired by individuals from birth as a biologically innate or a culturally "given" condition (Bourguignou, 1976). Recently, religion has become an individual preference or choice: this means that it is, generally, an achieved status. However, Indonesian societies-including the Sundanese-whose cultures are relatively inseparable from their religious values, still encourage their members to practice the culture-shaping religion of their ethnic group.

Globally, religion has a strong influence on human psychology (Paloutzian \& Park, 2005). From a psychological perspective, an individual's diversity system can be differentiated into several dimensions (Glock \& Stark, 1966): ideology, ritual, experiences, intellectualism and consequences. The diversity dimensions are also the cultural dimensions. Hence, it is logical that a cultured individual-whose culture is shaped by a certain religion-will also be a religious individual; not in the sense of "having a religious identity", but in the sense of "internalizing religious dimensions".

Islam, which has a strong influence on shaping Sundanese culture, contains a paradigm that the human is a spiritual being who always tries to find internal spiritual values (Frager, 2012). Life's goal-to find spiritual values-when internalized to the individual self, will create a self that dynamically moves to locate such spiritual values. Following the rituals and practices encouraged in the Islamic religion is one way to find the spiritual values. This motivates the Sundanese culture to encourage its individual members to conduct Islamic rituals and practices. These rituals and practices allow a religious self to take shape and the individual will think, feel and act in compliance with Sundanese culture. The religious self is the ideal self: this is the goal that individuals strive for during their self-development process.

The Indonesian religious self is reflected through the study and development of spiritual features as a psychological determinant by the Centre for Neuroscience, Health, and Spirituality (C-NET) of Sunan Kalijaga National Islamic University, Yogyakarta, Indonesia. This study identifies four spiritual dimensions that determine the religious self: 1) the meaning of life, 2) spiritual experiences, 3) positive emotions and 4) rituals (Pasiak, 2012). These four dimensions are in line with other studies on the relationship between the divine, spiritual and diversity aspects and the thinking, feeling and acting (self) aspects (Rauf, 2004; Ali, 2012; Chittick, 2007; Frager, 2012).

The first dimension-that the individual's meaning of life is to be God's servant-has consequences: in serving God, the human has social duties, and must appreciate other people's/society's welfare before their own personal wants. This encourages individuals to take responsibility for realizing public welfare. This first dimension is interrelated with the other three dimensions; including acquiring spiritual experiences and positive emotions that arise from finding the meaning of life. 
A Sundanese individual has the free will to choose the direction of their own self development. However, only the self-development that is oriented to other people's serenity and welfare will be regarded as the religious self or the Islamic self. A Muslim individual acknowledges that divine values exist in each person's conscience; this means that the individual simply needs to find and follow these. Such values are called natural loyalty and piousness (Rauf, 2004) or the spiritual soul (Frager, 2012). This is described by bio-molecular scientists as a loyalty that is instilled by God in everyone and is imprinted in life's blueprint (gene) as the potential for goodness or the tendency toward righteousness (Murakami, 2006). Neuroscientists call this the faith gene (Newberg \& Waldman, 2006).

What factors motivate Muslims to bind themselves to God's rules? Islam considers "life after death" to be a form of a human's accountability to God by their every action in the world. In the afterlife, the people who comply with God's rules will live happily in heaven, while the people who violate the rules will live in eternal misery in hell. Believing that God asks for accountability makes those that believe in it develop self-control and self-regulation to act according with the rules of God. Individuals must go through experiences in the form of rituals and practices until they find the meaning of life, spiritual experiences and positive emotions. For those who find them, their knowledge and faith will be an empirical knowledge (Ihsan, 2010) or a logical knowledge (Zainal, 2009).

\section{The Sundanese Self}

The fundamental self of the Sundanese people as a group is similar to that of other Eastern societies. Eastern psychologists believe that it is inaccurate to define an individuals' self in the Eastern context by detaching it from the individual context (Markus \& Kitayama, 2003); the context being a cultural one. Sundanese people-like those in other Eastern societies-grow and develop in relation to the cultural norms, rules and values that influence almost every aspect of their life. A Sundanese individual will always view themselves as part of their cultural context, and this, indirectly, means seeing themselves as part of their society. For a Sundanese individual, other people are very important, in that when viewing themselves, individuals always relates themselves toward their social context. This is what Markus and Kitayama call self-in-relation-to-other (interdependent view of the self) or how to view oneself as interdependent with others. The Sundanese culture emphasizes caring for and adjusting to others and, importantly, developing synergic interdependences with others.

Self-functioning may be influenced by external factors, such as social influence, or through self-control (Burkley, Anderson, \& Curtis, 2011), as is the case with Sundanese people. A Sundanese individual always feels interdependent (constantly in a relationship) with others and tries to maintain that interdependence by controlling themselves to harmonize with others. For example, a Sundanese woman is expected to take care of her parents when they get old, so she will choose a husband who will allow her to live close to her parents so that society recognizes her as a dutiful daughter. This is in contrast to Javanese women; their culture considers that when a girl gets married, she must be willing to follow her husband anywhere that he goes. A Javanese woman will choose a husband based on his independence and responsibility, rather than his willingness to live near her parents. Generally, Sundanese and Javanese men understand the demands of their own culture. Hence, in same-ethnic marriages, a Sundanese man will accept that his Sundanese wife will have to take care of her parents and he will also participate in that responsibility, while a Javanese man will accept the full responsibility of taking care of his wife without any outside help.

Markus and Kitayama (2003) note that a culture constructs a specific object in its own way, and represents it in memory in such a way that influences-and even determines-how someone thinks about the object. As an object, the self is treated in the same way: it is culturally constructed. In Western culture, the self is viewed as an independent object; while in Eastern culture, it is viewed as an interdependent object.

The interdependent construction of the self is based on the various realities found in Eastern culture in terms of stressing the importance of the connectedness and interdependence with others (Markus \& Kitayama, 2003). Schweder and Bourne (1984) called this the socio-centric self/social self. Concerning the interdependent view of the self, Markus and Kitayama illustrated that interdependent experiences are characterized by the view of the self as a part of a social relationship and that an individual's actions are determined by, connected to, and organized by the individual's view on the thoughts, feelings and actions of others in their relational network. Individuals with this type of self will feel most meaningful when they are in, and act in, the appropriate social relationship. They will be motivated to find a way to accommodate other people and to be part of various interpersonal relationship networks.

The concepts pertinent with this type of self-include socio-centric, collective and relational concepts. For someone with an interdependent self, other people are an inseparable part of the relevant situation or context. In 
almost every domain of social life, the opinion, capabilities and characteristics of the interdependent self must uphold their primary function: to maintain interdependence with others.

\section{Sundanese Self: Empirical Evidence}

This study examines the Sundanese self from the perspective of collectivism and religiousness. A total of 176 students (146 females and 30 males, with an average age of 21) of Sundanese origin who live in West Java (where the Sunda tribe originated) participated in this study. They were asked "How do you describe yourself when somebody asks?" Each respondent was given a sheet with 20 slots to write their responses outlining their own self-concept. The responses ranged between 3-20 statements, there were an overall total of 1322 statements and the average number of statements for each respondent was 7.51. The data were coded by the self-conceptualization that provided the analysis framework.

The results confirm the assumption that the Sundanese self has similar traits with other those of Eastern cultures in terms of the interdependent self (relatedness and interconnectedness). The results show that the interdependent self exists: an average of $56.13 \%$ of each respondent's total self-entity. Moreover, the study confirms that the religious self exists; however, the proportion $(16.00 \%)$ is smaller than that of the interdependent self.

In the context of the interdependent self, the "others" that the respondents identify themselves as being a part of (from highest to lowest) are nuclear family, extended family, ethnic group and close peer group. The respondents consider that those groups play a part in shaping their internal way of thinking (paradigm), principles, attitudes or feelings. The roles that those groups play are categorized into two: the expected group roles and the group roles that "had to be" listened to or followed to gain group acceptance.

From an interdependent self-perspective, the study concludes that the Sundanese always view themselves as part of a group, regardless of whether the group provides them with positive contributions or negative demands.

The interdependent self-characteristics found in Sundanese individuals are the trait and personality types that these individuals showed. The inventory of the participants' traits reveals that they were mostly interpersonally related, such as friendly, shy, open, introverted, reserved, sensitive, gregarious, loner, selfish, uncaring, firm, easily persuaded, humorous, easily bored and flexible. Hence, the study participants view themselves primarily from their relational position with others, rather than presenting individual self traits such as hardworking, disciplined and strong.

\section{Other Self Models}

The Sundanese cultural self is similar to the interdependent self (Markus \& Kitayama, 2003) or the self-in-relation-to-other-a way to view oneself as interrelated with others. Markus and Kitayama stated that based on the interdependent self's interdependency with its social context, the characteristics of the interdependent self cannot be identified precisely as a whole unit because its self-structure will change according to the specific social context that it interacts with. The unique self is created by the configuration of the various relationships that each person experienced and developed. This is apparent when the Sundanese self-interacts with a non-Sundanese. This is also conceptualized in relational-interdependent self-construal (RISC), which is the tendency to think of oneself in terms of your relationships with those close to you, and it influences relationship thoughts (e.g., closeness, commitment, perceived similarity) (Morry \& Kito, 2009).

The Sundanese self is also shown to have some traditional Chinese self-characteristics that are oriented toward social aspects, emphasizing roles, status, position, commitment, and responsibility (Kim \& Yang, 2010; Kim, 2011; Lu \& Yang, 2006).

Further, the religious self can be analogous with the interdependent self (Markus \& Kitayama, 2003), though it is not synonymous. From a religious self-aspect, the other is God, so the conceptualization becomes the self-in-relation-to-God. Individuals with a God-personal interdependent self will motivate themselves to consider the effect of their actions on the acceptance and reprisal of God for their thoughts, feelings, attitudes and behavior. In this context, they consider whether they have thought in line with God's commands and whether their behavior will please God so that God will reward them or whether God will be angry and punish them. This is consistent with the construction of the self as a dynamic process of spiritual development presented by $\mathrm{Tu}$ concerning the Chinese self (Lu \& Yang, 2006). However, there is one difference: in Chinese self-development, the spiritual aspect is Confucian, while in the Sundanese self, it is godliness.

\section{Acknowledgements}

This paper is partly based on a presentation at the Dies Natalis of the Psychology Faculty of Unpad in 2012. I extend my gratitude to the Ministry of National Education of Indonesia for the research grant provided through 
its DIPA budget at the Psychology Faculty of Unpad. I further thank the Komando Pasukan Khusus Tentara Nasional Indonesia Angkatan Darat (the Special Force of the Indonesian Army) for its support during the research and the opportunity to access the data of Ekspedisi Khatulistiwa 2012 and Ekspedisi NKRI Koridor Maluku dan Maluku Utara 2014.

\section{References}

Andersen, S. M., \& Chen, S. (2002). The Relational Self: An Interpersonal Social-Cognitive Theory. Psychological Review, 109(4), 619-645. http://dx.doi.org/10.1037/0033-295X.109.4.619

Andersen, S. M., Reznik, I., \& Glasman, N. S. (t.thn.). The Unconscious Relational Self. New York: Oxford University Press.

Armstrong, K. (2009). In Terjemahan (Ed.), The Case for God: What Religion Really Means. London: Penerbit Mizan.

Bennett, M. (2011, July/August). Children's social identities. Infant and Child Development, 20(4), 353-363. http://dx.doi.org/10.1002/icd.741

Boucher, H., \& Maslach, C. (2009). Culture and Individuation: The role of norms and self-construal. The Journal of Social Psychology, 149(6), 677-694. http://dx.doi.org/10.1080/00224540903366800

Bourguignou, E. (1976). Psychological Anthropology: An Introduction to Human Nature and Cultural Differences. New York, USA: Holt, Rinehart and Winston.

Brahm, A. (2006). Mindfullness, Bliss, and Beyond. Chuang, Penerj. Ehipassiko Foundation.

Burkley, E., Anderson, D., \& Curtis, J. (2011). You Wore Me Down: Self Control Strength and Social Influence. Social and Personality Compass, 5(7), 487-499. http://dx.doi.org/10.1111/j.1751-9004.2011.00367.x

Carlo, G., Eisenberg, N., Troyer, D., Switzer, G., \& Speer, A. (1991). The Altruistic Personality: In What Contexts Is It Apparent? Journal of Personality and Social Psychology, 61(3), 450-458. http://dx.doi.org/10. 1037/0022-3514.61.3.450

Coyle, A., \& Lyons, E. (2011). The Social Psychology of Religion: Current Research Themes. Journal of Community and Applied Social Psycholog, 21, 461-467. http://dx.doi.org/10.1002/casp.1121

Daniel, L. (2011, August 31). Spiritual but Not Religious? Please Stop Boring Me. United Church of Christ online magazine.

Fang, Y. C. (2010). Konsepsi Cina tentang Self. In D. U. Kim, K. S. Yang, \& K. K. Hwang (Eds.), Indigenous and Cultural Psychology.

Fitts, W. H. (1971). The Self Concept and Self Actualization. Western Psychological Services.

Forgas, J., \& Williams, K. (2003). The Social Self: Introduction and Overview. USA: Taylor \& Francis, Inc.

Frager, R. (2012). Sufi Talks: Teachings of an American Sufi Sheikh. Weathon: Quest Books.

Fuller, R. C. (2001). Spiritual But Not Religious: Understanding Unchurched America. Oxford University Press. http://dx.doi.org/10.1093/0195146808.001.0001

Gabriel, S., Harris, B., Carvallo, M., \& Troisi, J. D. (2012, June 11). The Iterconnected Self: The Social Individual is More Than Just Social + Individual. Social and Personality Psychology Compass, 826-839. http://dx.doi.org/10.1111/j.1751-9004.2012.00463.x

Gaertner, L., Sedikides, C., \& O'mara, E. (2008, February 5). On The Motivational Primacy of the Individual Self: 'I' Is Stronger than 'We'. Social and Personality Psychology Compass, 1913-1929. http://dx.doi.org/10. 1111/j.1751-9004.2008.00142.x

Glock, C. Y., \& Stark, R. (1969). Religion and Society in Tension. Chicago: Rand McNally \& Company.

Glock, C., \& Stark, R. (1966). Beliefs of Christianity and anti-Semitism. New York: Harper \& Row.

Goble, F. G. (1971). The Third Force: The psychology of Abraham Maslow. New York: Washington Square Press.

Hall, C. S., \& Lindzey, G. (1978). Theories of Personality. New York: John Wiley \& Sons.

Hardie, E., Critchley, C., \& Morris, Z. (2006). Self-coping complexity: Role of self-construal in relational, individual, and collective coping styles and health outcomes. Asian Journal of Social Psychology, 9(3), 224-235. http://dx.doi.org/10.1111/j.1467-839X.2006.00201.x 
Hardjoprakoso, S. (1956). Candrajiwa Indonesia; Sebagai Dasar suatu Psikhotherapi. Jakarta, Indonesia: Manuskrip yang tidak dipublikasikan.

Hepper, E. G., Sedikides, C., \& Cai, H. (2013). Self-Enhancement and Self-Protection Strategies in China: Cultural Expression of Fundamental Human Motive. Journal of Cross-Cultural Psychology, 5-23. http://dx.doi.org/10.1177/0022022111428515

Hill, P. C., \& Pargament, K. I. (2008). Advances in the conseptualisation and measurement of religion and spirituality: Implication for physical and mental health research. Psychology of Religion and spirituality, 3-17. http://dx.doi.org/10.1037/1941-1022.S.1.3

Ihsan, F. (2010). Filsafat Ilmu. Jakarta: Penerbit Rineka Cipta.

Jackson, B. R., \& Bergeman, C. (2011, May). How does religiosity enhance well-being? The role of perceived control. Psychology of Religion and Spirituality, 3(2), 149-161. http://dx.doi.org/10.1037/a0021597

Kim, J., Kim, M. S., Kam, K. Y., \& Shin, H. C. (2003). Influence of self-construal's on the perception of different self-presentation styles in Korea. Asian Journal of Social Psychology, 6, 89-101. http://dx.doi.org/ 10.1111/1467-839X.t01-1-00013

Kim, S. (2011). The Anatomy of Confucian Communitarianism: The Confucian Social Self and Its Discontent. The Phiosophical Forum, Inc, 111-130. http://dx.doi.org/10.1111/j.1467-9191.2011.00382.x

Kim, U., \& Yang, K. S. (2010). In K. K. Hwang (Ed.), Indigenous and Cultural Psychology (1st ed.). New York, USA: Springer Science + Business Media, LLC.

Kim, Y. H., Chiu, C. Y., Cho, S., Au, E. W., \& Kwak, S. N. (2014). Aligning inside and outside perspective of the self: A cross-cultural difference in self-perception. Asian Journal of Social Psychology, 17, 44-51. $\mathrm{http}: / / \mathrm{dx}$. doi.org/10.1111/ajsp.12042

Kopassus. (2012). Ekspedisi Khatulistiwa. Tentara Nasional Indonesia Angkatan Darat, Komando Pasukan Khusus. Jakarta: Komando Pasukan Khusus TNI AD.

Kopassus. (2014). Ekspedisi NKRI Koridor Maluku dan Maluku Utara. Tentara Nasional Indonesia Angkatan Darat, Komando Pasukan Khusus. Jakarta: Komando Pasukan Khusus.

Lalwani, A. K., \& Shavitt, S. (2009). The "Me" I Claim to Be: Cultural Self-Construal Elicits Self-Presentational Goal Pursuit. Journal of Personality and Social Psychology, 97(1), 88-102. http://dx.doi.org/10.1037/a00 14100

Laurin, K., Kay, A. C., \& Fitasimmons, G. M. (2012). Differgent Effects of Activating Thoughts of God on Self-Regulation. Journal of Personality and Social Psychology, 102(1), 4-21. http://dx.doi.org/10. $1037 / \mathrm{a} 0025971$

Logel, C., \& Cohen, G. L. (2011). The Role of the Self in Physical Health: Testing the Effect of a Values-Affirmation Intervention on Weight Loss. Psychological Science, 23(1), 53-55. http://dx.doi.org/10. $1177 / 0956797611421936$

Lu, L., \& Yang, K. (2006). Emergence and composition of the traditional-modern bicultural self of people in contemporary Taiwanese societies. Asian Journal of Social Psychology, 9(3), 167-175. http://dx.doi.org/10. 1111/j.1467-839X.2006.00195.x

Madon, S., Willard, J., Guyl, M., \& Scherr, K. C. (2011). Self-Fulfilling Prophecies: Mechanism, Power, and Links to Social Problems. Social and Personality Psychology Compass.

Markus, H., \& Kitayama, S. (2003). Culture and the Self. Implication for Cognition, Emotion, and Motivation. In D. M. A. Hogg (Ed.), Social Psychology (Vol. IV). London: SAGE Publications.

Mead, G. H. (1913). The Social Self. Journal of Philosophy, Psychology and Scientific Methods, (10), 374-380. http://dx.doi.org/10.2307/2012910

Miller, R. (1991). Educating the True Self: Spiritual Roots of the Holistic Worldview. Journal of Humanistic Psychology, 53-67. http://dx.doi.org/10.1177/0022167891314004

Mookherjee, N. (2013, March). Introduction: Self in South East Asia. Journal of Historical Sociology, 26(1). http://dx.doi.org/10.1111/johs. 12008

Morin, A. (2011, May 10). Self-Awareness Part 1: Definition, Measures, Effects, Functions, and Antecedents. Social and Personality Psychology Compass, The Author, 807-823. 
Morin, A. (2011, May 12). Self-Awareness Part 2: Neuroanatomy and Importance of Inner Speech. Social and Personality Psychology Compass, 1004-1017. http://dx.doi.org/10.1111/j.1751-9004.2011.00410.x

Morry, M. M., \& Kito, M. (2009, June). Relational-Interdependent Self-Construal as a Predictor of Relationship Quality: The Mediating Roles of One's Own Behaviors and Perceptions of the Fulfillment of Friendship Functions. The Journal of Social Psychology, 149(3), 205-222. http://dx.doi.org/10.3200/SOCP.149.3.305 $-322$

Morry, M. M., Reich, T., \& Kito, M. (2010, July/August). How Do I See You Relative to Myself? Relationship Quality as a Predictor of Self- and Partner-Enhancement Within Cross-Sex Friendships, Dating Relationships, and Marriages. The Journal of Social Psychology, 150(4), 369-393. http://dx.doi.org/10.1080 /00224540903365471

Murakami, K. (2006). The Divine Code of Life: Awaken Your Genes and Discover Hidden Talents. New York: Beyond Words Publishing, Inc.

Nasional, P. B. D. P. (2011). Kamus Besar Bahasa Indonesia (4th ed.). Jakarta: Departemen Pendidikan Nasional.

Newberg, A., \& Waldman, M. R. (2006). Born to Believe: God, Science, and the Origin of Ordinary and Extraordinary Beliefs. New York: Free Press.

Nezlek, J. B., Schaafsma, J., Safron, M., \& Krejtz, I. (2012). Self-Construal and the Intra-and Interethnic Social Interactions of Ethnic Minorities. Journal of Cross-Cultural Psychology, 43(2). http://dx.doi.org/10.1177/ 0022022111399647

Ng, H. S., Ha, S. M., \& Lai, J. C. (2010). Dynamic bicultural brains: fMRI study of their flexible neural representation of self and significant others in response to culture primes. Asian Journal of Social Psychology, 13, 83-91. http://dx.doi.org/10.1111/j.1467-839X.2010.01303.x

Ninin, R. H. (2012). Living with Well-being: Indigenous Perspective on Sources of Foregoing Happiness and potential Sources of Forthcoming Well-being. 4th Asian Psychological Association Conference. Jakarta: Asian Psychological Association.

Paloutzian, R. F., \& Park, C. L. (Eds.). (2005). Handbook of the Psychology of Religion and Spirituality. New York: The Guilford Press.

Parrinder, G. (2000). The Routledge Dictionary of Religious and Spiritual Quotations. London: Routledge Taylor and Francis Group.

Pasiak, T. (2012). Tuhan dalam Otak Manusia. Bandung, Jawa Barat, Indonesia: Mizan.

Peetz, J., \& Wilson, A. E. (2008, February 6). The Temporally Extended Self: The Relation of Past and Future Selves to Current identity, Motivation, and Goal Pursuit. Social and Personality Psychology Compass, Journal Compilation, 2090-2106.

Perreira, T. L. (2010, April 13). "Die before you die": Death Meditation as Spiritual Technology of the Self in Islam and Buddhism. The Muslim World, 100(2-3), 247-267. http://dx.doi.org/10.1111/j.1478-1913.2010. 01319.x

Quinn, N. (2006). The Self: Anthropological Theory. Journal of Historical Sociology, 6(3), 362-384. http://dx. doi.org/10.1177/1463499606066893

Rauf, I. F. A. (2004). In D. Mardina, \& M. R. P. Atmoko (Eds.), What's Right with Islam: A New Vision for Muslims and the West. New York: HarperCollins.

Reber, A. (1985). Dictionary of Psychology. USA: The Penguin Books.

Schaefer, R. T. (2009). Sociology: A brief introduction. USA: The McGraw-Hill Companies, Inc.

Schlegel, R., \& Hicks, J. (2012, December 5). The True Self and Psychological Health: Emerging Evidence and Future Directions. Social and Personality Psychology Compass.

Schmeichel, B. J., Vohs, K. D., \& Baumeister, R. F. (2003). Intellectual Performance and Ego Depletion: Role of the Self in Logical Reasoning and Other Information Processing. Journal of Personality and Social Psychology, 85(1), 33-46. http://dx.doi.org/10.1037/0022-3514.85.1.33

Sedikides, C., Hart, C. M., \& De Cremer, D. (2008, February 6). The Self in Procedural Fairness. Social and Personality Psychology Compass, Journal Compilation, 2107-2124. 
Slife, B. D., \& Richardson, F. C. (2010, March/April). Review of Relational Being: Beyond Self and Community. The Journal of Social Psychology, 150(2), 226-230. http://dx.doi.org/10.1080/00224540903 535289

Triatmo, F. A. (2014). www.imankatolik.or.id/10perintah.html. Diambil kembali dari Iman Katolik: Media Informasi dan Sarana Katekese. Retrieved form http:/www.imankatolik.or.id

Wijaya, I. N., Bagus, I. G., Paramartha, K., Suastika, I. M., \& Nuarca, I. K. (2013). Dinamika Budaya Hindu Dharma di Indonesia. Denpasar: Udayana University Press.

Xie, D., Leong, F. T., \& Feng, S. (2008). Culture-specific personality correlates of anxiety among Chinese and Caucasian college students. Asian Journal of Social Psychology. http://dx.doi.org/10.1111/j.1467-839X. 2008.00253.x

Zainal, A. (2009). In S. L. Azizah (Ed.), Filsafat Manusia: Memahami Manusia melalui Filsafat. Bandung: PT Remaja Rosdakarya.

\section{Copyrights}

Copyright for this article is retained by the author(s), with first publication rights granted to the journal.

This is an open-access article distributed under the terms and conditions of the Creative Commons Attribution license (http://creativecommons.org/licenses/by/3.0/). 